\title{
On Kșemendra's Version of the Prātihāryasūtra
}

\author{
YAMASAKI Kazuho
}

\section{Introduction}

Kșemendra (ca. 990-1077 A.D.) composed a Buddhist narrative work Bodhisattvāvadānakalpalatā (hereafter Av-klp). The fourteenth chapter of this work is devoted to the story of miracles (Prātihāryasūtra, hereafter PrSū). ${ }^{1)}$ While Nakagawa [1982] and Okamoto[2008] have analyzed and contrasted the versions of the PrSu found in the Pāli canon and Tibetan translations, they do not consider Kșemendra's version in their study. ${ }^{2)}$ Focusing on Kșemendra's version of PrSū, thus, this paper aims at showing which version of PrSū Kșemendra consults in composing his own version of PrSū by comparing Kșemendra's version of PrSū and other versions.

\section{Structure of PrSū in Av-klp}

Before proceeding to the central argument, it will be useful to outline the narrative events within Kșemendra's PrSū in sixty-one verses of the Av-klp. ${ }^{3)}$ The elements of PrSū in Av-klp are as follows:

(a) Introductory verse (v. 1)

(b) Heretics feel jealousy toward the Buddha who is in high favor with King Bimbisāra and are possessed by Mãra. (vv. 2-6)

(c) The heretics ask the permission of King Bimbisāra to conduct a contest of miracles against the Buddha; King Bimbisāra refuses it. (vv. 7-9)

(d) The heretics ask the permission of King Prasenajit to conduct the contest; King Prasenajit grants it and asks the Buddha to take part in the contest. (vv. 10-28)

(e) The story of Prince Kāla. (vv. 29-40)

(f) King Prasenajit builds a hall for the contest of miracles. (v. 41)

(g) The miracle of the Buddha causes a kalpa-tree to shoot from the earth. (v. 42)

(h) The Buddha emits a brilliant light from his body. (vv. 43-46)

(i) The miracle of the Buddha causes lotus-flowers to shoot from the earth and creates Buddhas. 
(vv. 47-49)

(j) Gods praise the Buddha. (vv. 50-51)

(k) The Buddha preaches the law. (vv. 52-54)

(1) Audiences give up the false notion of personality. (v. 55)

(m) The heretics are overwhelmed by the power of the Buddha's miracles and cannot work any miracle. (v. 56)

(n) Yakșa raises up the wind by which the heretics are swept away. (v. 57)

(o) The Buddha preaches that people should take refuge in the Buddha, dharma, and sanga. (vv. 58-59)

(p) The Buddha converts the heretics and goes back to Rājagrha. (vv. 60-61)

\section{Classification of PrSū versions}

The versions of PrSū which I have taken into consideration are as follows:

- Divyāvadāna, chap. 12: Prātihāryasūtra (Divy) [ca. 10th century A.D.?] ${ }^{4)}$

- 'dul ba phreng tshegs kyi gzhi (Tib), translated by Vidyākaraprabha, Dharmaśribhadra, dPal 'byor [ca. 8-9th century A.D.] ${ }^{5)}$

- Kên-pên-shuo-ji-ch 'ieh-yu-pu-p ‘i-nai-yeh-tsa-shih (根本説一切有部毘奈耶雑事), vol. 26, translated by I-ching (義淨) [710 A.D. ${ }^{6)}$

- Hsien-yü-ching (賢愚經), vol. 2, chap. 14: Chiang-liu-shih-pi ‘in (降六師品), translated by Hui-chüeh (慧覚) [445 A.D.] ${ }^{7}$ )

- Ssŭ-fên-lü (四分律), vol. 51, translated by Buddhayaśas (佛陀耶舎) [408 A.D.] ${ }^{8)}$

- Fo-pên-hsing-ching (佛本行經), vol, 4, chap. 20: Tai-shên-pien-pi in (大神變品), translated by Pao-yün (寶雲) [424-453 A.D. ${ }^{9)}$

- Fa-chü-p i-yü-ching (法句譬嗡經), chap. 30: Ti-yü-pi'in (地獄品), translated by Fa-chü and Fa-li (法炬 , 法立) [209-306 A.D.] ${ }^{10)}$

- Jātaka \#483 Sarabhamigajātaka [?] 11)

- Dhammapadatțhakathā Yamakappātihhāriyavatthu [ca. 450 A.D.] ${ }^{12)}$

These versions are classified into two basic groups: MSV group (the texts which pertain to the Mūlasarvāstivāda tradition) and non-MSV group. Nakagawa[1982] has already pointed out that the versions of PrSū in Divy, Tib and Kên-pên-shuo-ji-ch 'ieh-yu-pu-p 'i-nai-yeh-tsashih have nearly the same elements. They form the MSV group.

Elements (b) - (f), (h) $-(\mathrm{j}),(1)-(\mathrm{m})$ and (o) in Kṣemendra's text, as previously outlined, are shared by other versions in the MSV group. While $(b)-(d),(f)-(j)$ and $(m)$ are also common to the non-MSV group, (e) (Divy 153.22-155.12; D44a3-45a5; P41b1-42b5; T330b14-330c25), (1) (D48a4-6; P45b2-4; T331c15-17), ${ }^{13)}$ and (o) (Divy 164.7-16; D52a3-6; 
P49a8-49b3; T333a1-10) are peculiar to the MSV group.

We should specifically note with regard to element (b) (Divy 143.9-145.22; D40a3-40b4; P37b2-38a4; T329a5-329b19):

- The Pāli versions of PrSū and PrSū in the Ssŭ-fên-lü contain a reference both to the Buddha who forbids his disciples to use their miraculous powers (Jâtaka 263.10-23; Dhammapadatthakathā 203.13-204.12; Ssŭ-fên-lü T946b13-947a11) and to the monk Piṇ̣̂ola-Bhāradvāja who gets a wooden bowl by using his miraculous power; they do not contain a reference to Măra.

- PrSū in the Hsien-yü-ching, in which the Buddha works miracles in front of King Bimbisāra (T361b2-5), and PrSū in the Fo-pen-hsing-ching, in which the heretics who vainly boast of their knowledge harbor enmity toward the Buddha (T84b22-84c6), contain a reference to Māra (Hsien-yü-ching T360c17-361b2; Fo-pên-hsing-ching T84c6-14).

- PrS̄̄ in the Fa-chü-p' i-yü-ching does not contains a reference to Māra but to the heretics who feel jealousy toward the Buddha (T598c2-6).

What is immediately apparent is that both Kșemendra's version and the versions in the MSV group refer both to heretics and Māra. This fact strongly suggests that Kṣemendra consults PrSū transmitted in the Mūlasarvāstivāda sect in composing his version of PrSū.

\section{Discrepancies between PrSū in MSV and PrSū in Av-klp}

As shown above, Kșemendra's version of PrSū and the versions in the MSV group have many common elements. However, there are narrative elements that appear in MSV group versions that are not included in Kșemendra's version:

(I) Enumeration of Tathāgatas' obligations. (Divy 150.15-26; D42b5-7; P40a5-7; T329c26330a2)

(I) The Buddha recollects that the past Buddhas worked miracles. (Divy 147.22-25; D42b7-43a1; P40a7-8; T330a3-4)

(III) Heretics seek help from their allies. (Divy 151.19-153.20; D43a3-44a2; P40b2-41b1; T330a9330b14)

(N) Disciples of the Buddha offer to take part in the contest against the heretics. (Divy 159.20-160.18; D48b3-49b3; P46a2-46b8; T331c27-332a13)

(V) The Buddha works the Twin Miracle (yamakaprātihārya). (Divy 160.1-11; D49b7-50a4; P47a5-47b1; T332a21-26)

(VI) Pūraṇa meets an eunuch; disciples of Pūraṇa meet an harlot. (Divy 164.26-165.14, 165.16-166.2; D52b6-53a3, 53a7-53b4; P50a3-7, 50b5-8; T333a27-333b13, 333b23-333c8)

(VII) Pūraṇa commits suicide. (Divy 165.14-15; D53a3; P50a7-8; T333b13-14)

Kșemendra's version omits outright elements (I) - (IV), however with regard to elements 
(V) - (VII) the following substitutions are noted:

- Instead of element (V), Kșemendra's version of PrSū has element (g), which is found in the Pāli versions (Jātaka 264.28-265.5; Dhammapadatthakathā 206.18-207.14) and in the versions in the Hsien-yü-ching (T362c8-11) and the Ssü-fên-lü (T949a5-7). ${ }^{14)}$

- Instead of elements (VI)-(VII), Kșemendra's version has element (p), which is found in the version in the Fo-pên-hsing-ching (T86c21). ${ }^{15)}$

We can see that in his version of PrSū, Kșemendra omits the elements (I) - (IV) which the versions of the MSV group commonly have and that he replaces elements (V) - (VII) with elements found in the versions of PrSū in the non-MSV group. It is significant that Kṣemendra is familiar with the PrSū transmitted by the versions of the non-MSV group. It is not unusual for Kșemendra to embellish his retelling of stories transmitted in the the Mūlasarvāstivāda sect with story elements derived in consultation with non-MSV versions, which is seen in other chapters of Av-klp. ${ }^{16)}$

\section{Conclusion}

(1) Kșemendra's version of PrSū contains a majority of elements which are common to the versions in the MSV group. This shows that Kșemendra consults the PrSū transmitted in the Mūlasarvāstivāda sect.

(2) However, Kșemendra's version of PrSū contains a few elements which are not found in the versions of the MSV group or contains elements which have been replaced with non-MSV elements.

(3) The main source of Kșemendra's version of PrSū is undoubtedly the PrSū transmitted in the Mūlasarvāstivāda sect. But it is important to note that Kṣemendra is aware of $\operatorname{PrS} \bar{u}$ as narrated in the versions of the non-MSV group. Kṣemendra does not intend simply to rewrite PrSū transmitted in the Mūlasarvāstivāda sect. As a poet, he is takes liberty to make his story more compelling through narrative embellishments of non-MSV origin.

\footnotetext{
* My special thanks are due to Dr. David Mellins for correcting my English and giving many suggestions. I also wish to thank Professor Kiyoshi Okano for providing me the copy of the Tibetan block print of the Fifth Dalai Lama (Tōhoku \#7034).
}

Notes

1) S. Ch. Das \& Vidyābhūṣaṇa, eds., "Prātihāryāvadāna," in Avadana Kalpalatā, (Calcutta, 
1888), 1: 410-429. See also J. W. de Jong, "Notes on the Text of the Bodhisattvāvadānakalpalatā Pallavas 7-9 and 11-41," Hokke Bunka Kenkyū 22 (1996): 26-28.

2 ) See Masanori Nakagawa, "Shaeijō jimpen setsuwa" (On Prātihāryasūtra), Journal of Indian and Buddhist Studies 60 (1982): 657-658; Kensuke Okamoto, "Shaeijō ni okeru ikyōto to butsudeshi shāriputra no arasoi" (The Contest between Śāriputra and Heretics at Śrāvastī), (paper presented at the Fifteenth Conference of the History of Indian Thought, Kyoto, December 2008).

3 ) The following meters are used in PrSū in Av-klp: anuștubh, 43 stanzas (70.49\%); vasantatilakā, 15 stanzas $(24.59 \%)$; mālinī, 1 stanza $(0.16 \%)$; sāardūlavikrì dita, 2 stanzas $(3.28 \%)$. Of the anuștubh stanzas: pathy $\bar{a}, 68$ half-stanzas $(79.07 \%)$; na-vipula, 9 half-stanzas $(10.47 \%)$; $m a$-vipula, 4 half-stanzas $(4.65 \%)$; bha-vipula , 5 half-stanzas $(5.81 \%)$. It may be worth pointing out, in passing, that Kșemendra uses a considerable amount of vipula half-stanza to compose his version of PrSū. In the Kumārasambhava (Wiesbaden, 1980), Kālidāsa uses 30 vipulā halfstanzas $(10.26 \%)$.

4 ) C. B. Cowell \& R. A. Neil, eds., "Prātihāryasūtra" in The Divyāvadāna, (Cambridge, 1886), 143-166. The date of Divy has not been fixed. According to Hiraoka, Divy is dated around the eleventh century A.D. (Satoshi Hiraoka, Setsuwa no kōkogaku (Archaeology of Narrative), (Tokyo, 2002), 135-139). However, as Bongard-Levin \& Volkova points out, a few stanzas of Av-klp are incorporated into the text of Divy. We may say that Divy is dated around the end of the eleventh century A.D. (G. M. Bongard-Levin \& O. F. Volkova, "The Kuṇāla Legend and An Unpublished Aśokāvadānamālā Manuscript," Indian Studies Past \& Present 5 (1963): 117).

5 ) $\mathrm{D} \# 6,40 \mathrm{a} 1-53 \mathrm{~b} 5 ; \mathrm{P} \# 1035,37 \mathrm{a} 8-50 \mathrm{~b} 2$.

6) T\#1451, 329a1-333c14.

7) $\mathrm{T} \# 202,360 \mathrm{c} 14-366 \mathrm{a} 10$.

8 ) T\#1428, 946b13-952b15.

9) $\mathrm{T} \# 193,83 \mathrm{c} 27-87 \mathrm{a} 3$.

10) $\mathrm{T} \# 211,598 \mathrm{c} 1-599 \mathrm{c} 18$.

11) V. Fausbøll, ed., "Sarabhamigajātaka" in The Jātaka 4 (London, 1879), 263-275.

12) Helmer Smith, ed., "Yamakappātihāryiyavatthu," in The Commentary on the Dhammapada 3 (London, 1925), 199-230.

13) This element is not found in PrSũ in Divy.

14) This fact has been pointed out by Okamoto [2008].

15) This fact has also been pointed out by Okamoto $[2008]$.

16) See M. Cone \& R. Gombridge, The Perfect Generosity of Prince Vessantara. (Oxford, 1977), xxxix.

〈Key words〉 Prātihāryasūtra, Divyāvadāna, Mūlasarvāstivādavinaya, Bodhisattvāvadānakalpalatā, Kṣemendra

(Graduate Student, Hiroshima University) 